\title{
PKM Penggunaan Obat Rasional Pada Lansia Perempuan Desa Kayuuwi dan Desa Kayuuwi I Untuk Mencipatakan Lansia Sehat, Mandiri, Aktif dan Produktif
}

\author{
Olvie Syenni Datu ${ }^{1 *}$, Julianri Sari Lebang ${ }^{1}$, \\ ${ }^{\mathbf{1}}$ Program Studi Farmasi, Fakultas Matematika Dan Ilmu Pengetahuan Alam \\ Universitas Sam Ratulangi \\ *Penulis Korespondensi, Olvie Syenni Datu Program Studi Farmasi FMIPA Universitas Sam Ratulangi Manado \\ 95115. Email: olvie.datu@unsrat.ac.id
}

\begin{abstract}
ABSTRAK
Penduduk lanjut usia terus mengalami peningkatan seiring kemajuan di bidang kesehatan yang ditandai dengan meningkatnya angka harapan hidup dan menurunnya angka kematian. Perkembangan demografi ini membawa dampak di bidang kesehatan, ekonomi, dan sosial. Penurunan fungsi tubuh seiring kelanjutusiaan dapat menimbulkan permasalahan kesehatan, yang meningkatkan risiko disabilitas. Kondisi ini menghadapkan lansia pada berbagai kebutuhan tambahan dari sisi kesehatan dan asistensi. Mitra pada kegiatan ini adalah kelompok fungsional lansia desa Kayuuwi dan Kayuuwi I, Kecamatan Kawangkoan barat, Kabupaten Minahasa. Sebagian besar lansia di desa Kayuuwi dan Kayuuwi I memiliki penyakit degeneratif sehingga mengkonsumsi obat yang jumlahnya lebih dari satu yang berpotensi menimbulkan permasalahan terkait penggunaan obat seperti terapi ganda, kelebihan dosis, interaksi obat dan meningkatnya efek samping. Kegiatan ini bertujuan untuk memberikan pengetahuan bagi mitra mengenai penggunaan obat yang rasional dan pemeriksaan kesehatan lansia. Kegiatan ini dilakukan melalui beberapa metode seperti penyuluhan mengenai penggunaan obat yang rasional, caracara agar tidak lupa meminum obat, serta bagaimana menghindari efek obat yang tidak dikendaki. Selain itu juga dilakukan diskusi dimana secara bergantian lansia menyampaikan permasalahan penggunaan obat yang dihadapi sehingga diberikan solusi cara untuk mengatasinya. Pada kegiatan ini dibagikan materi yang telah disusun dan brosur-brosur penggunaan obat yang benar dan paket kesehatan seperti masker, handsanitizer dan vitamin untuk meningkatkan derajat kesehatan masyarakat pada massa pandemi covid19. Pada kegiatan ini juga dilakukan pemeriksaan kesehatan pada lansia meliputi pengukuran tekanan darah, pengukuran kadar kolesterol, kadar glukosa darah dan kadar Asam urat. Kegiatan berlangsung dengan baik dan pada akhir kegiatan dilakukan post test untuk mengetahui pemahaman para lansia. Berdasarkan hasil post test menunjukan bahwa telah tejadi peningkatan pengetahuan lansia mengenai penggunaan obat yang rasional dan lansia mengetahui status kesehatannya.
\end{abstract}

Kata Kunci: Lansia, Penggunaan Obat Rasional

\begin{abstract}
The elderly population continues to increase in line with progress in the health sector, which is marked by life expectancy and decreasing mortality rates. These demographic developments have an impact on the health, economic and social fields. The decline in bodily functions with advancing age can lead to health problems, which increase the risk of disability. This condition exposes the elderly to various additional needs in terms of health and assistance. Partners in this activity are the elderly functional group in Kayuuwi and Kayuuwi I villages, West Kawangkoan District, Minahasa Regency. Most of the elderly in Kayuuwi and Kayuuwi villages have degenerative diseases so they take drugs that are related to more than one cause that may cause problems such as multiple therapies, overdose, drug interactions and side effects. This activity aims to provide knowledge for partners regarding the rational use of drugs and health checks for the elderly. This activity is carried out through several methods such as counseling on rational drug use, ways not to forget to take medication, and how to prevent unwanted drug effects. In addition, discussions were also held which took turns overcoming the problems of using the drugs given so that solutions to overcome them were carried out. In this activity, materials that have been compiled and brochures on the use of drugs and health packages such as masks, hand sanitizers and
\end{abstract}


JPAI

Jurnal Perempuan dan Anak Indonesia
Volume 3 Nomor 1, [ September 2021 ] hal 1-6

DOI:https://doi.org/10.35801/jpai.3.1.2021.36175

vitamins are distributed to improve public health status during the covid-19 pandemic. This activity also carried out health checks on the elderly including measuring blood pressure, measuring cholesterol levels, blood glucose and uric acid. went well and at the end of the activity a post test was carried out to determine the understanding of the elderly. Based on the results of the post test, it showed that there had been an increase in knowledge about rational drug use and the elderly knew their health status.

Keywords: Elderly, Rational use Drug

\section{PENDAHULUAN}

\section{Analisis Situasi}

Proses menua adalah proses alami yang disertai adanya penurunan kondisi fisik, psikologis maupun sosial yang saling berinteraksi satu sama lain. Keadaan itu cenderung berpotensi menimbulkan masalah kesehatan secara umum pada lansia (Azizah, 2011). Lanjut usia menurut UU Nomor 13 Tahun 1998 adalah seseorang yang telah mencapai usia 60 (enam puluh) tahun ke atas. Penduduk lanjut usia terus mengalami peningkatan seiring kemajuan di bidang kesehatan yang ditandai dengan meningkatnya angka harapan hidup dan menurunnya angka kematian. Perkembangan demografi ini dapat membawa dampak di bidang kesehatan, ekonomi, dan social (BPS, 2019). Berdasarkan hasil survei sunsesnas di Indonesia terdapat 9,60\% (25,66 Juta) penduduk lansia dan Sulawesi Utara berada pada urutan ke-5 propinsi dengan jumlah populasi lansia terbanyak yaitu 11,15\% (BPS, 2019).

Pasien pada usia lanjut rentan dengan perubahan yang berkaitan dengan kondisi fisiologis, peningkatan faktor risiko untuk penyakit yang terkait dengan penuaan, dan peningkatan konsekuensi dalam penggunaan obat (Dasopang, 2015). Pemberian obat pada pasien usia lanjut merupakan tantangan yang kompleks dan memerlukan pertimbangan cermat antara manfaat dan potensi bahaya. Kompleksitas muncul karena perubahan terkait usia antara lain adanya perubahan komposisi dan fungsi tubuh, komorbiditas, termasuk gangguan sensorik dan kognitif, serta adanya polifarmasi. Polifarmasi berhubungan dengan efek samping dan lama perawatan di rumah sakit (Fauziah, 2020). Reaksi efek samping obat, termasuk interaksi obat pada pasien geriatri yang merupakan masalah umum terjadi di rumah sakit dan merupakan penyebab penting pada tingkat morbiditas dan mortalitas. Risiko interaksi obat meningkat sesuai dengan jumlah obat yang diresepkan dan pasien geriatri biasanya mendapatkan obat yang lebih banyak dibandingkan pasien usia lainnya (Zulkarnaini, 2019).

Mitra yang terlibat pada pengabdian ini adalah kelompok fungsional lansia Desa Kayuuwi dan Desa Kayuuwi I Kecamatan Kawangkoan Barat, Kabupaten Minahasa, berjarak kurang lebih $44 \mathrm{Km}$ dari kota manado, dengan sebagian besar penduduk bekerja sebagai tukang, petani dan pensiunan.

Berdasarkan hasil wawancara mengenai status kesehatan mitra (sampel mewakili lansia dari desa Kayuuwi dan Kayuuwi I) didapatkan beberapa infoemasi yaitu $100 \%$ lansia yang ada di lansia menderita penyakit degeneratif dan semuanya menggunakan obat-obat kronis, jumlah obat yang dikonsumsi bervariasi dari 35. Selain itu didapatkan infromasi bahwa $60 \%$ pasien mengetahui nama obat dan indikasi penggunaanya namun $40 \%$ pasien tidak menghapal nama obat dan waktu minum obat tersebut dan bahkan pernah mengkonsumsi obat yang sama dihari yang sama dikarenakan kemasan yang berbeda dan warna obat yang berbeda.

Hasil ini menggambarkan ada masalah yang harus diselesaikan karena jika tidak diselesaikan dapat menimbulkan masalah baru terkait dengan status Kesehatan lansia. Seperti kelebihan dosis, terapi ganda, interaksi obat, efek samping.Mengingat semakin meningkatnya jumlah penduduk lanjut usia di Indonesia, maka pengembangan di bidang Kesehatan perlu untuk 
perhatikan karena apabila lansia dalam kondisi sehat, aktif, dan produktif, maka akan berdampak positif terhadap angka rasio ketergantungan serta kondisi sosial ekonomi keluarga, masyarakat, dan negara.

\section{Tujuan dan Manfaat Kegiatan}

Kegiatan ini bertujuan untuk meningkatkan pemahaman lansia mengenai obat-obat yang rasional, memberikan konsultasi pada lansia agar mereka memahami dengan jelas obat yang dikonsumsi, cara memberikan label yang jelas pada setiap obat yang digunakan untuk menghindari salah pakai obat memberikan Penjelasan mengenai reaksi obat tidak dikehendaki dan cara-cara mengatasi hal tersebut dan melakukan pemeriksaan kesehatan bagi lansia meliputi pengukuran tekanan darah, pemeriksaan pengukuran kadar kolesterol, glukosa darah dan kadar asam urat.

\section{METODE PELAKSANAAN}

\section{Sasaran kegiatan}

Sasaran pelaksanaan kegiatan ini adalah lansia yang berada di desa Kayuuwi dan Kayuuwi I kecamatan Kawangkoan Barat, Kabupaten Minahasa.

\section{Lokasi kegiatan}

Kegiatan ini dilaksanakan di Ruang pertemuan lansia desa Kayuuwi dan Kayuuwi I

\section{Metode yang digunakan :}

Adapun beberapa metode yang digunakan dalam kegiatan ini adalah :

\section{a) Penyuluhan Interaktif}

Penyuluhan dilakukan pada lansia desa Kayuuwi dan Kayuuwi I dilaksanakan dengan tetap memperhatikan protocol Kesehatan pada masa pandemi covid-19. Dengan kriteria yang hadir adalah lansia yang sehat. Sebelum pelaksanaan kegiatan dilakukan pengukuran suhu tubuh, mencuci tangan dan diatur jarak tempat duduk. Penyuluhan dilakukan dengan menggunakan poster, leafleat dan materi yang telah disusun. Materi penyuluhan meliputi obat-obat yang sering digunakan pada lansia dan cara pemakaian yang benar, perbedaan obat generik dan obat bermerek, mengenal reaksi efek samping obat dan cara mengatasinya, mengetahui mengenai interaksi obat sehingga lansia memahami bahwa obat tertentu tidak dapat diberikan secara bersamaan dan bagaimana cara mengenali obat dengan isi zat berkhasiat yang sama namun dengan nama dagang yang berbeda untuk menghindari terapi ganda.

b) Diskusi

Untuk lebih memastikan lansia desa Kayuuwi dan Kayuuwi I memahami apa yang disampaikan. Diskusi dilakukan berupa tanya jawab maupun pertanyaanpertanyaan yang diajukan oleh tim pengabdian

c) Konsultasi

Tahapan konsultasi dibuka bagi peserta yang memiliki masalah-masalah spesifik yang sulit untuk jelaskan pada forum diskusi sehingga dilakukan konsultasi agar semua peserta dapat terjangkau dan menjawab setiap masalah.

d) Pemeriksaan Kesehatan

Setelah semua rangkaian kegitan penyuluhan selesai dilaksanan, selanjutnya dilakukan pemeriksaan Kesehatan bagi lansia pemeriksaan Kesehatan dilakukan dengan melibatkan kader Kesehatan di desa Kayuuwi dan Kayuuwi I. Pemeriksaan Kesehatan meliputi pengukuran tekanan darah, total kolesterol, kadar glukosa darah, dan kadar asam urat Kegiatan ini dilksanan dengan menerapkan protocol Kesehatan ketat. Tujuanya agar lansia senantiasa mengetahui kondisi fisiknya.

\section{HASIL DAN PEMBAHASAN}

Kegiatan ini dilaksanakan pada bulan September 2021 di desa Kayuuwi dan desa Kayuuwi I. kegiatan ini dapat berjalan dengan baik walaupun dimasa pandemi covid-19 
JPAI

Jurnal Perempuan dan Anak Indonesia

dimana kehadiran mitra, dalam hal ini lansia sangat antusias mengikuti kegiatan. Kegiatan ini dilaksanakan bertahap sesuai dengan metode pelaksanaan yang telah direncakanan.

Proses menua merupakan proses berkurangnya daya tahan tubuh dalam menghadapi rangsangan dari dalam maupun luar tubuh. Pada masa ini, sedikit demi sedikit seseorang akan mengalami kemunduran fisiologis, psikologis, dan sosial, dimana perubahan ini akan berpengaruh terhadap seluruh aspek kehidupan termasuk pada aspek Kesehatan (BPS, 2019).

Pasien pada usia lanjut rentan dengan perubahan yang berkaitan dengan kondisi fisiologis, peningkatan faktor risiko untuk penyakit yang terkait dengan penuaan, dan peningkatan konsekuensi dalam penggunaan obat (Dasopang, 2015). Separuh lansia Indonesia mengalami keluhan kesehatan dan persentasenya semakin meningkat seiring dengan bertambahnya umur lansia. Kecenderungan meningkatnya keadaan patologis pada lansia menyebabkan peningkatan konsumsi obat sehingga memperbesar adanya risiko drug-related problems (DRPs) termasuk reaksi efek samping, interaksi obat, ataupun reaksi toksik (Mulyani, 2020).

Metode yang digunakan pada kegiatan ini adalah penyuluhan interaktif, yaitu tim pengabdian membagikan materi dan brosurbrosur mengenai penggunaan obat yang rasional pada lansia. Materi yang disusun adalah mengenai data status kesehatan lansia, permasalahan-permasalahan yang berkaitan dengan pengobatan lansia dan cara-cara memilih dan menggunaan obat yang rasional bagi lansia.

Setelah seluruh materi diberikan, tahapan selanjutnya adalah diskusi dimana secara bergantian lansia menyampaikan permasalahan kesehatan yang dialaminya dan permasalahan terkait dengan penggunaan obatnya. Hampir semua lansia sering mengalami masalah yaitu lupa meminum obat disebabkan karena jumlah obat yang harus dikonsumsi lebih dari satu, selain itu lansia belum bisa membedakan nama generik maupun nama obat bermerek sehingga pada beberapa lansia mengalami terapi ganda. Pada kegiatan diskusi tim pengabdian memberikan beberapa solusi dengan melakukan demonstrasi kepada lansia agar tidak mudah lupa dalam minimum obat melalui cara mengatur obat sesuai dengan waktu konsumnsinya menggunakan kotak obat harian yang dapat dilakukan oleh lansia sendiri atau dibantu oleh anggota keluarga.

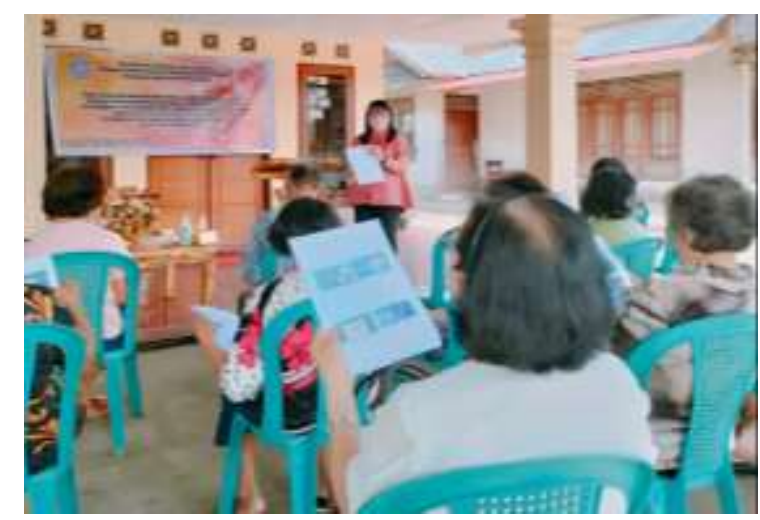

Gambar 1. Sesi Penyuluhan

Pada tahap diskusi juga dilakukan pembagian brosusr kepada lansia mengenai cara membedakan obat generik dan generik bermerek untuk menghindari obat dengan isi zat berkhasiat sama yang dikonsumsi 2 kali. Para lansia sangat antusias mengikuti kegiatan yang ditandai dengan banyaknya pertanyaan. Pada kegiatan ini juga diberikan informasi yang benar mengenai bagaimana menggunakan obat tradisional yang benar meliputi cara memilih tanaman yang berkhasiat maupun cara penggunaanya sehingga tidak terjadi kelebihan dosis ataupun salah dalam pemilihan rute pemberian, serta mengedukasi lansia untuk cermat mengamati setiap rekasi setelah pemberian obat dan obat tradisional seperti pusing, mual dan muntah serta reaksi alergi.

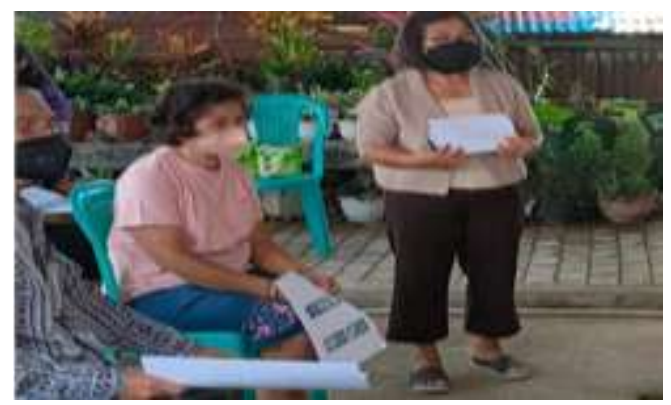


JPAI

Jurnal Perempuan dan Anak Indonesia

Gambar 2. Perwakilan Lansia pada Sesi Diskusi

Setelah dilakukan penyuluhan pada hari berikutnya dilakukan pemeriksaan Kesehatan lansia meliputi tekanan darah, kadar glukosa darah, kadar kolesterol dan kadar asam urat.

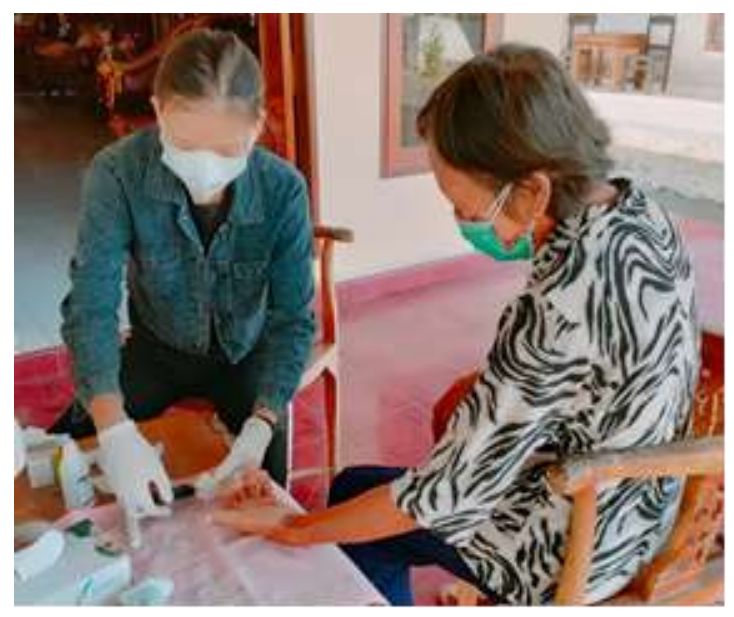

Gambar 3. Pemeriksaan Kesehatan Lansia

Hasil pemeriksaan tekanan darah dan kolesterol menunjukkan hasil yang bervariasi pada rentang normal dan pada beberapa lansia dalam kondisi yang tinggi. Pada lansia yang memiliki kadar kolesterol yang tinggi dan tekanan darah tinggi diberikan edukasi mengenai penggunaa obatnya dan pengaturan pola makan yang benar. Pada hasil pemeriksaan kadar glukosa darah Sebagian besar lansia ada pada kondisi yang normal. Sedangkan pada pemeriksaan kadar asam urat sebagian besar menunjukkan kadar asam urat yang tinggi berada pada rentang $8-12 \mathrm{mg} / \mathrm{dL}$. Berdasarkan hasil pemeriksaan Kesehatan dilakukan wawancara dan diperoleh hasil terdapat pengaruh pola konsumsi masyarakat terhadap pola penyakit yang ada dimana lansia cendenrung untuk mengkonsumsi makan yang tinggi purin seperti : jeroan, kacang-kacangan, protein hewani tinggi, alkohol yang dapat meningkatkan kadar asam urat. Hal ini sejalan dengan penelitian Kussoy et al, 2019 menujukkan terdapat hubungan antara kebiasaan makan makanan tinggi purin dengan kadar asam urat.
Untuk melihat apakah mitra dapat memahami materi yang disampaikan pada akhir kegiatan dilakukan post test dalam bentuk pertanyaan singkat mengenai bagaimana cara membedakan obat generik dan obat bermerek, bagaimana cara mengkonsumsi obat yang benar, bagaimana mengamati rekasi obat yang tidak dikendaki dan Tindakan-tindakan yang dapat dilakukan untuk mecegah penyakit degeneratif. Berdasarkan hasil post test didapatkan mitra dapat menjawab pertanyaan dengan benar hal ini menunjukkan bahwa telah terjadi kenaikan pengetahuan mengenai penggunaan obat kepada lansia selain itu lansia dapat mengetahui status kesehatan mereka sehingga dapat terus dilakukan pengecekan pada fasilitas pelayanan Kesehatan.

\section{KESIMPULAN}

Berdasarkan kegiatan dapat disimpulkan

1. Lansia telah memahami bagaimana cara menggunakan obat yang rasional

2. Lansia telah mengetahui status kesehatannya sehingga dapat dilakukan pemeriksaan kesehatan secara berkala

\section{SARAN}

Kegiatan penyuluhan penggunaan obat dan pemeriksaan Kesehatan pada lansia dilaksanakan secara berkala agar lansia terhindar dari penggunaan obat yang tidak rasional dan derjat kesehatan lansia semakin baik menuju lansia sehat, mandiri, aktif dan produktif.

\section{UCAPAN TERIMAKASIH}

Terima kasih kepada Lembaga Penelitian dan Pengabdian Masyarakat Universitas Sam Ratulangi (LPPM-Unsrat) yang telah membiayai kegiatan Program Kemitraan Masyarakat tahun pendanaan 2021. Terima kasih juga disampaikan kepada mitra kegiatan ini yaitu kelompok fungsional lansia desa Kayuuwi dan Kayuuwi I Kecamatan Kawangkoan barat, Kabupaten Minahasa. 


\section{DAFTAR PUSTAKA}

Badan Pusat Statistik (BPS). 2019. Statistik Penduduk Usia Lanjut. Penerbit Badan Pusat Statistik.

Dasopang ES., Urip ., Dharma L. 2015. Polifarmasi dan Interaksi Obat Pasien Usia Lanjut Rawat Jalan dengan Penyakit Metabolik. Jurnal Farmasi Klinik Indonesia 4(4); 235-241.

Kussoy VFM., Kundre R., Wowiling F. 2019. Kebiasaan Makan Makanan Tinggi Purin Dengan Kadar Asam Urat di Puskesmas. Journal Keperawatan 7(2): 1-7

Yuda, A., Arie S., Catur D. S., Gesnita N., Gusti N.V. Ahmad1., Mufarrihah1., Yunita N. 2014. Profil Praktek Pengelolaan Obat pada Lansia di Surabaya. Jurnal Farmasi Komunitas 1(1): 24-29.

Fauziah H., Roza M, Rose D M. 2020. Polifarmasi pada Pasien Geriatri. Jurnal Human Care 5(3): 804-812.

Zulkarnaini A., Rose D M. 2019. Gambaran Polifarmasi Pasien Geriatri Dibeberapa Poliklinik RSUP Dr. M. Djamil Padang. Jurnal Kesehatan Andalas 8 (1)

Mulyani T., Rukminingsih. 2020. Evaluasi peresepan pada Pasien Geriatri di Klinik Penyakit Dalam Instalasi Rawat Jalan RSUD K.R.M.T Wongsonerogo Semarang. Jurnal Riset Kefarmasian Indonesia 2(2) 